\title{
KONSEP PERADILAN PIDANA TERINTEGRASI DALAM PENEGAKAN HUKUM BERKEADILAN
}

\author{
Hajairin \\ Sekolah Tinggi Ilmu Hukum Muhammadiyah Bima \\ Jln. Anggrek Nomor 16 Ranggo Nae Kota Bima \\ Email: hajairinbima91@gmail.com
}

\section{Abstrak}

Peradilan pidana terintegrasi dalam mewujudkan penegakan hukum pidana yang berkeadilan diperlukan singkronisasi subtansi hukum pidana, struktur hukum pidana dan budaya hukum. Penelitian ini bertujuan untuk mengetahui konsep peradilan pidana terintegrasi dan singkronisasi penegakan hukum pidana berkeadilan . Metode penelitian yang digunakan yakni penelitian hukum normatif dengan pendekatan perundang-undangan, kasus, historis, konseptual dan analitis dengan sumber bahan hukum yakni Bahan hukum primer dan Bahan hukum sekunder. Teknik pengumpulan bahan hukum dilakukan dengan cara menganalisis asas-asas, konsepsi-konsepsi, pandanganpandangan, doktrin-doktrin hukum serta isi kaidah hukum diperoleh, sementara teknik analisis bahan hukum yang digunakan dalam penelitian ini adalah yuridis konseptual. Temuan dalam hasil penelitian ini menunjukan bahwa untuk mewujudkan peradilan pidana terintegrasi diperlukan singkronisasi substansi hukum pidana, struktur hukum pidana dan budaya hukum sebagai upaya dalam mewujudkan penegakan hukum pidana berkeadilan, konsep penegakan hukum berkeadilan yakni keadilan administratif dan keadilan subtantif. Singkronisasi 
subtansi hukum pidana baik hukum pidana materil maupun hukum pidana formil menjadi penting dilakukan agar menghindari terjadinya konflik hukum. Singkronisasi struktur hukum memberi penjelasan bahwa semua lembaga penegak hukum seperti polisi, jaksa, hakim, advokat dan lembaga permasyarakatan, tidak boleh merasa paling benar dan saling menyalahkan antara satu dengan yang lain. Sementara budaya hukum haruslah menyatu dengan subtansi hukum dan di pertimbangkan oleh struktur hukum dalam penegakan hukum pidana.

\section{Keywords: Peradilan Terintegrasi; Penegakan Hukum; Berkeadilan}

\section{Pendahuluan}

Dalam mewujudkan peradilan pidana terintegrasi diperlukan singkronisasi subtansi hukum pidana baik hukum pidana materil maupun hukum pidana formil menjadi penting dilakukan agar menghindari terjadinya konflik hukum. Singkronisasi struktur hukum memberi penjelasan bahwa semua lembaga penegak hukum seperti polisi, jaksa, hakim, advokat dan lembaga permasyarakatan, tidak boleh merasa paling benar dan saling menyalahkan antara satu dengan yang lain. Sementara budaya hukum haruslah menyatu dengan subtansi hukum dan di pertimbangkan oleh struktur hukum dalam penegakan hukum pidana. Namun dalam praktik penegakan hukum yang sedang berlangsung saat ini, pengutamaan nilai kepastian hukum lebih menonjol dibandingkan dengan rasa keadilan masyarakat. ${ }^{1}$

Secara umum Friedman menjelaskan bahwa sistem hukum terdiri dari tiga elemen yaitu, substansi hukum, struktur hukum

1 Syamsuhadi Irsyad (2013) Tanggapan Atas Kajian Pemetaan Pembangunan Struktur Hukum Di Indonesia (Fokus Pada Pembangunan Lembaga Peradilan), Kosmik Hukum, Volume 13 Nomor 2 Hal 1. 
dan budaya hukum. Salah satu sub peradilan pidana yang penting terintegrasi adalah struktur hukum, sebab singkronisasi fungsional antar institusi lembaga penegak hukum akan menentukan penegakan hukum berkeadilan dapat di wujudkan atau tidak. Hubungan fungsional dan institusional antar masingmasing sub bagian dalam rangka penegakkan hukum. Sedangkan sebagai sebuah proses, dimaksudkan bahwa peradilan menempuh proses sesuai dengan ketentuan hukum pidana dan hukum acara pidana yang berlaku. ${ }^{2}$

Hemat penulis untuk mengintegrasikan sistem hukum pidana berarti singkronisasi hukum pidana materil maupun hukum pidana formil, kemudian singkronisasi struktur hukum menandakan lembaga penegak hukum harus terintegrasi. Sebab penegakan terus berjalan, tapi perubahan paradigma hukum merupakan fenomena yang sangat berpengaruh dalam menentukan penegakan hukum yang berkeadilan. Di sisi lain hukum belum sepenuhnya mampu menjadi pemenuhan dahaga di tengah hausnya akan keadilan dan kesejahteraan masyarakat. Masih banyak sekali kasus-kasus hukum yang belum terselesaikan dengan tuntas sehingga berpengaruh terhadap kepercayaan rakyat pada penegakan hukum. ${ }^{3}$ Berdasarkan latar belakang masalah dalam penelitian diatas dapatlah di rumuskan masalah yakni Bagaimana Konsep Peradilan Pidana Terintegrasi.?, dan Bagaiamana Peradilan Pidana Terintegrasi Dalam Mewujudkan Penegakan Hukum Berkeadilan.? Dengan tujuan penelitian ini adalah

2 Bawekes Jevons, (2013) Integrated Criminal Custice System Terhadap Sistem Peradilan Tindak Pidana Perikanan, Fakultas Hukum Unsrat, Volume 2, Nomor 7 Hal 93-101.

3 Setyo Langgeng, (2018) Peran Advokat Sebagai Penegak Hukum Dalam Mendukung Terwujudnya Sistem Peradilan Pidana Terpadu Dalam Penegakan Hukum Pidana Di Indonesia," Jurnal Daulat Hukum, Universitas Islam Sultan Agung, Volume 1, Nomor. 1 Hal 138-56. 
untuk mengetahui konsep peradilan pidana terintegrasi dalam penegakan hukum pidana yang berkeadilan.

\section{Metode Penelitian}

Metode penelitian ini menggunakan Jenis penelitian hukum normative yakni penelitian inventarisasi hukum positif, menemukan asas dan doktrin hukum, singkronisasi perundang-undangan dengan Pendekatan Pertama Pendekatan perundang-undangan (Statute Approach) yakni menelaah semua peraturan perundang-undangan yang bersangkut paut dengan permasalahan (isu hukum) yang sedang di hadapi, Kedua Pendekatan Kasus (Case Approach) yakni dilakukan dengan menelaah pada kasus-kasus yang berkaitan dengan isu hukum yang di hadapi, Ketiga pendekatan historis (Historical Approach) yakni untuk memahami nilai-nilai sejarah yang menjadi latar belakang serta yang berpengaruh terhadap nilai-nilai yang terkandung dalam peraturan perundang-undangan. Keempat Pendekatan Konseptual (Conceptual Approach) yakni pandangan atau doktrin yang berkembang dalam ilmu hukum dapat menjadi pijakan untuk membangun argumentasi hukum ketika menyelesaikan isu hukum yang di hadapi dan Kelima pendekatan analitis (Analytical Approach) yakni untuk menelaah makna dan istilah hukum dan dilihat dalam praktik hukum dan menelaah pengertian, asas, kaidah, system dan konsep yuridis. ${ }^{4}$

Sumber bahan hukum yang digunakan dapat di bagi dalam dua yakni Bahan hukum primer berfokus pada integrated criminal justice system dalam penegakan hukum pidana berkeadilan dan Bahan hukum sekunder yaitu bahan yang memberikan penjelasan tentang integrated criminal justice system dalam penegakan hukum pidana berkeadilan. Teknik pengumpulan bahan hukum dilakukan dengan cara menganalisis asas-asas, konsepsi-konsepsi, pandangan-pandangan, doktrin-doktrin

${ }^{4}$ Irwansyah, (2021) Penelitian Hukum Pilihan Metode \& Praktik Penulisan Artikel, Mirra Buana Media, Yogyakarta, Hal 133-152

Sangaji Jurnal Pemikiran Syariah dan Hukum 
hukum serta isi kaidah hukum diperoleh melalui dua referensi utama yaitu a) Bersifat umum, terdiri dari buku-buku, teks, ensiklopedia b) Bersifat khusus, terdiri dari laporan hasil penelitian, majalah maupun jurnal. Sementara teknik analisis bahan hukum yang digunakan dalam penelitian ini adalah yuridis konseptual. ${ }^{5}$

\section{Hasil Dan Pembahasan}

\section{Konsep Peradilan Pidana Terintegrasi}

Dalam penegakan hukum pidana melalui peradilan pidana terintegrasi diperlukan sinkrionisasi secara menyeluruh seperti kebijakan yang integral dan sistemik dengan harapan adanya penegakan hukum yang berkepastian dan berkeadilan. Konsep sistem peradilan pidana yang integral sehingga terwujud suatu kinerja Sistem peradilan pidana (SPP) yang optimal dalam penegakan hukum pidana, dengan melakukan pendekatan sistem dan reorientasi struktural, substansial dan kultural terhadap sistem peradilan pidana. $^{6}$ Dengan demikian sebenarnya makna sistem peradilan pidana terpadu atau integrated criminal justice system, adalah sinkronisasi atau keselarasan, yang dapat dibedakan dalam Sinkronisasi struktural (structural syincronization), Sinkronisasi substansial (substansial syincronization) dan Sinkronisasi kultural (cultural syincronization). diharapkan dapat terjalin dalam rangka penegakan hukum yang berkeadilan.

Konsep penegakan hukum pidana pada dasarnya merupakan system kekuasaan dalam penegakan hukum terdiri dari kekuasaan penyidikan (Badan Penyidikan), Kekuasaan

5 Jhonny Ibrahim (2014) Teori dan Metodologi Penelitian Hukum Normatif, Banyumedia Publishing, Surabaya, Hal, 295

${ }^{6}$ Achmad Budi Waskito (2018) Implementasi Sistem Peradilan Pidana Dalam Perspektif Integrasi, Jurnal Daulat Hukum Universitas Islam Sultan Agung Volumen 1, Nomor $1: 287$. 
Penuntutan (Badan Penuntutan), Kekuasaan Mengadili (Badan Pengadilan), dan Kekuasaan Pelaksana Pidana (Badan Eksekusi) yang merupakan satu kesatuan sistem penegakan hukum pidana yang integral atau sering dikenal dengan istilah Sistem Peradilan Pidana Terpadu (integrated criminal justice system). Salah satu bentuknya yakni dengan penerapan sistem peradilan pidana secara terpadu dan terintegrasi antara aparat penegakan hukum antara lain kepolisian, kejaksaan, pengadilan dan advokat. $^{7}$

Hal ini didukung oleh ciri pendekatan Sistem Peradilan Pidana (SPP) terpadu menurut Romli Atmasasmita, adalah titik berat pada koordinasi dan sinkronisasi komponen peradilan pidana (kepolisian, kejaksaan, pengadilan dan lembaga pemasyarakatan) pengawasan dan pengendalian penggunaan kekuasaan oleh komponen peradilan pidana. Efesiensi sistem penanggulangan kejahatan lebih utama dari penyelesaian perkara, penggunaan hukum sebagai instrumen untuk memantapkan the administration of justice. ${ }^{8}$ Yang ingin di capai dalam peradilan pidana terintegrasi adalah adanya pertanggungjawaban dari semua pihak yang terlibat dalam penegakan hukum untuk mewujdukan keadilan subtantif, tanpa saling merasa benar dan saling menyalahkan. Selain itu juga dapat mewujudkan penegakan hukum yang berorientasi pada kesejahteraan masyarakat.

7 Agus Suryadi dan Supardi (2021) Mewujudkan Sistem Peradilan Pidana Terpadu Melalui Case Management System (Studi Di Kejaksaan Negeri Kota Bogor), Jurnal Suara Hukum Volume 3, Nomor 1: 10.

8 Romli Atmasasmita dalam Edi Setiadi dan Kristian (2017) Sistem Peradilan Pidana Terpadu Dan Sistem Penegakan Hukum Di Indonesia, Penerbit Prenadamedia Group, Jakarta, Hal, 28

Sangaji Jurnal Pemikiran Syariah dan Hukum 


\section{Peradilan Pidana Terintegrasi Dalam Mewujudkan Penegakan Hukum Berkeadilan}

Hukum sebagai suatu sistem, dapat berperan dengan baik dan benar di tengah masyarakat jika instrumen pelaksanaannya dilengkapi dengan kewenangan-kewenangan dalam bidang penegakan hukum. Pembangunan hukum adalah mewujudkan fungsi dan peran hukum di tengah-tengah masyarakat Indonesia memiliki kultur masyarakat yang beragam dan memiliki nilai yang luhur, tentunya sangat mengharapkan keadilan dan kemanfaatan yang dikedepankan dibandingkan unsur kepastian hukum. Sebagai benteng terakhir harapan para pencari keadilan, maka lembaga peradilan ke depan diharapkan benar-benar mandiri, independent dan imparsial, sehingga dapat memberikan pelayanan keadilan yang lebih baik kepada masyarakat pencari keadilan tanpa kekhawatiran akan adanya intervensi pihak manapun terhadap proses peradilan.

Sebab dalam praktik kita melihat ada undang-undang sebagian besar dipatuhi dan ada undang-undang yang tidak dipatuhi dalam dinamika penegakan hukum pidana kita saat ini, sehingga sistem hukum jelas runtuh jika setiap orang tidak mematuhi undang undang dan undangundang itu akan kehilangan maknanya, Penegakan hukum pada prinsipnya harus dapat memberi manfaat atau berdaya guna "utility" bagi masyarakat, namun di samping itu masyarakat juga mengharapkan adanya penegakan hukum untuk mencapai suatu keadilan. ${ }^{9}$ Selain itu Peradilan pidana kita saat ini perlu menggunakan pendekatan tertentu dan pemahaman yang komprehensif tetang konsep peradilan pidana, ruang lingkup peradilan pidana, tujuan peradilan pidana, dengan rekonstruksi

${ }^{9}$ Hajairin (2017) Kriminologi Dalam Hukum Pidana (Suluh Media (Anggota Graha Ilmu) Yogyakarta, Hal 73. 
peradilan pidana di masa lalu dan masa depan peradilan pidana. ${ }^{10}$

Hal ini terjadi karena adanya tarik menarik antara kepentingan mencari kebenaran serta menjatuhkan pidana paling tepat dengan segala kewenangan represif penguasa yang terkait dengannya, pada satu pihak, dengan kepentingan memberikan perlindungan hukum pada perseorangan yang ditempatkan dalam kerangka kepatutan yuridis pada lain pihak. Khususnya berkenaan dengan yang disebut terakhir persoalan terpenting ialah bagaimana mengembangkan hukum pidana beradab dalam kerangka negara hukum (rechtsstaat). ${ }^{11}$ Sistem peradilan pidana terpadu di Indonesia belum dilaksanakan secara terintegrasi. Hal ini salah satunya disebabkan karena subsub system peradilan pidana (kepolisian, kejaksan, kehakiman, lembaga pemasyarakatan) di Indonesia belum mengerti secara utuh apa sebenarnya yang dimaksud dengan konsep peradilan pidana terintegrasi. ${ }^{12}$

Penulis menganggap konsep penegakan hukum haruslah di diskusikan sehingga bisa dirumuskan dalam bentuk konsep hukum yang tidak hanya dapat memberikan keadilan secara prosedural tetapi juga keadilan subtantif dalam masyarakat, itulah yang penting untuk di wujudkan dalam kehidupan sosial sekarang ini, memang hal ini menjadi perhatian dalam penegakan hukum pidana lebih lagi dalam pemahaman tentang konsep sosial dan hukum positif secara nasional dalam

10 Hajairin (2019) Peradilan Pidana Prespektif Abolisionisme: Kritik Terhadap Model Pemidanaan Fisik Menuju Pemidanaan Psikis, Jurnal Sangaji: Pemikiran Syariah Dan Hukum Institut Agama Islam Muhammadiyah Bima Volume 3, Nomor $2: 212$.

11 Septa Candra Dkk (2012) Hukum Pidana Dalam Perspektif, Pustaka Larasan, Denpasar Bali, Hal 59.

12 Kristian \& Christine Tanuwijaya, (2015) Penyelesaian Perkara Pidana Dengan Konsep Keadilan Restoratif (Restorative Justice) Dalam Sistem Peradilan Pidana Terpadu Di Indonesia, Jurnal Mimbar Justitia 1, Nomor 2 : 60.

Sangaji Jurnal Pemikiran Syariah dan Hukum 
ketatanegaraan kita saat ini dan harus di laksanakan secara serius dalam hukum pidana di Indonesia, sebagai bagian dari penegakan hukum kita saat ini, sehingga apa yang tergambarkan dalam tujuan hukum untuk keadilan, kepastian dan kemanfaatan dapat tercapai dalam kehidupan masyarakat.

Dengan demikian sistem peradilan pidana pelaksanaan dan penyelenggaan penegakan hukum pidana melibatkan badan-badan yang masing- masing memiliki fungsi sendirisendiri. Penegakkan hukum yang mengandung prinsip proporsional adalah bagaimana penegakkan hukum berjalan sedemikian rupa, sehingga tidak hanya menegakkan aturan normatifnya (aspek kepastian hukumnya) tetapi juga aspek filosofisnya (aspek dan nilai keadilannya), dimana dalam hal ini bertujuan untuk menuju terwujudnya penegakkan hukum secara proporsional dimaksud, sangat diperlukan media dan perangkat yang namanya sistem peradilan. ${ }^{13}$

Berdasarkan berbagai kajian menunjukan bahwa peradilan pidana terintegrasi ini penting untuk di maksimalkan dalam penegakan hukum dan keadilan, jika dalam subtansi hukum memiliki kelemahan maka di perlukan pembaharuan hukum pidana, struktur hukum menterjemahkan bagaimana polisi, jaksa, hakim dan lembaga permasyarakatan penting untuk tidak saling menabrak kewenangan, artinya meski masing-masing meliki kewenagan yang berbeda tetapi wajib ada konektifitas dalam menciptakan keadilan subtansial, budaya hukum dapat dilihat dalam singkronisasi nilai, adat atau kebiasaan menjadi satu norma atau kaidah yang terintegrasi kedalam subtansi hukum pidana dalam mewujudkan penegakan hukum yang berkeadilan.

13 Nyoman Satyayudhadananjaya, (2014) Sistem Peradilan Pidana Terpadu (Integreted Criminal Justice System) Di Kaji Dari Perspektif Sub Sistem Kepolisian," Jurnal Ilmiah Ilmu Agama Dan Ilmu Hukum, Volume 9, Nomor 1 Hal : 88. 


\section{Simpulan}

Peradilan pidana terintegrasi sangat diperlukan, sebab singkronisasi substansi hukum pidana, struktur hukum pidana dan budaya hukum menjadi upaya dalam mewujudkan penegakan hukum pidana berkeadilan. Konsep penegakan hukum berkeadilan yakni keadilan administratif dan keadilan subtantif. Singkronisasi subtansi hukum pidana baik hukum pidana materil maupun hukum pidana formil menjadi penting dilakukan agar menghindari terjadinya konflik hukum. Singkronisasi struktur hukum memberi penjelasan bahwa semua lembaga penegak hukum seperti polisi, jaksa, hakim, advokat dan lembaga permasyarakatan, tidak boleh merasa paling benar dan saling menyalahkan antara satu dengan yang lain. Sementara budaya hukum haruslah menyatu dengan subtansi hukum dan di pertimbangkan oleh struktur hukum dalam penegakan hukum pidana.

Sangaji Jurnal Pemikiran Syariah dan Hukum 


\section{Daftar Pustaka}

Agus Suryadi dan Supardi (2021) Mewujudkan Sistem Peradilan Pidana Terpadu Melalui Case Management System (Studi Di Kejaksaan Negeri Kota Bogor), Jurnal Suara Hukum Volume 3, Nomor 1: 10.

Achmad Budi Waskito (2018) Implementasi Sistem Peradilan Pidana Dalam Perspektif Integrasi, Jurnal Daulat Hukum Universitas Islam Sultan Agung Volumen 1, Nomor $1: 287$.

Bawekes Jevons, (2013) Integrated Criminal Custice System Terhadap

Sistem Peradilan Tindak Pidana Perikanan, Fakultas Hukum Unsrat, Volume 2, Nomor 7 Hal 93-101.

Hajairin (2019) Peradilan Pidana Prespektif Abolisionisme: Kritik Terhadap Model Pemidanaan Fisik Menuju Pemidanaan Psikis, Jurnal Sangaji: Pemikiran Syariah Dan Hukum Institut Agama Islam Muhammadiyah Bima Volume 3, Nomor 2 : 212.

Hajairin (2017) Kriminologi Dalam Hukum Pidana (Suluh Media (Anggota Graha Ilmu) Yogyakarta, Hal 73.

Irwansyah, (2021) Penelitian Hukum Pilihan Metode \& Praktik

Penulisan Artikel, Mirra Buana Media, Yogyakarta, Hal 133152

Jhonny Ibrahim (2014) Teori dan Metodologi Penelitian Hukum Normatif, Banyumedia Publishing, Surabaya, Hal, 295

Kristian \& Christine Tanuwijaya, (2015) Penyelesaian Perkara Pidana Dengan Konsep Keadilan Restoratif (Restorative Justice) Dalam Sistem Peradilan Pidana Terpadu Di Indonesia, Jurnal Mimbar Justitia 1, Nomor $2: 60$.

Nyoman Satyayudhadananjaya, (2014) Sistem Peradilan Pidana Terpadu (Integreted Criminal Justice System) Di Kaji Dari Perspektif Sub Sistem Kepolisian," Jurnal Ilmiah Ilmu Agama Dan Ilmu Hukum, Volume 9, Nomor 1 Hal : 88. 
Romli Atmasasmita dalam Edi Setiadi dan Kristian (2017) Sistem

Peradilan Pidana Terpadu Dan Sistem Penegakan Hukum Di

Indonesia, Penerbit Prenadamedia Group, Jakarta, Hal, 28

Syamsuhadi Irsyad (2013) Tanggapan Atas Kajian Pemetaan

Pembangunan Struktur Hukum Di Indonesia (Fokus Pada

Pembangunan Lembaga Peradilan), Kosmik Hukum, Volume 13 Nomor 2 Hal 1.

Setyo Langgeng, (2018) Peran Advokat Sebagai Penegak Hukum Dalam Mendukung Terwujudnya Sistem Peradilan Pidana Terpadu Dalam Penegakan Hukum Pidana Di Indonesia," Jurnal Daulat Hukum, Universitas Islam Sultan Agung, Volume 1, Nomor. 1 Hal 138-56.

Septa Candra Dkk (2012) Hukum Pidana Dalam Perspektif, Pustaka Larasan, Denpasar Bali, Hal 59. 